\title{
MORPHOFUNCTIONAL RECONSTRUCTIONS OF THE EPIPHYSAL-PARATHYROIDE AXIS STRUCTURAL COMPONENTS OF RATS IN THE PERIOD OF READAPTATION AFTER PROLONGED EXPOSURE TO HEAVY METALS ${ }^{*}$
}

\author{
Hryntsova N. B., Tymakova O. O., Romaniuk A. M. \\ Sumy State University, Medical Institute, Department of Morphology, \\ Department of Pathological Anatomy, Sumy, Ukraine \\ natalia.gryntsova@gmail.com
}

An important environmental problem in some northern regions of Ukraine today is the accumulation of heavy metal salts (zinc, chromium, lead, manganese, copper and iron) in soil, water and air, which is observed in various combinations depending on the region and causes adverse effects on people's health. Such a negative impact determines the development and course of oncological pathology, disorders of homeostasis and morphological transformations in various tissues [1, 2]. The endocrine system together with the immune and nervous systems maintains homeostasis in the body. The central link, in particular the epiphysis (pineal gland), is involved in triggering a stress response, limiting its further development while preventing adverse effects on the body.
The main regulator of the the pineal gland functional activity is the photoperiod. The pineal gland provides the secretion of a number of vital substances - hormones (melatonin and serotonin) and neuropeptides, including peptide hormone, which regulates calcium metabolism. The pineal gland is involved in the organization of the circadian rhythm in the total calcium concentration of the blood plasma. This seems to be extremely important, since calcium plays a leading role in ensuring numerous physiological processes in the body (muscle contraction, cell membranes' permeability, secretion of hormones and enzyme production). Together with the hypothalamus, the pineal gland serves as the central pacemaker of the circadian rhythmicity of physiological processes. In addition,

* The work was performed in accordance with the research plan of the Medical Institute at Sumy State University and is part of the planned research project at the Department of Pathological Anatomy "Morphogenesis of general pathological processes» (state registration No. 013U003315) and «Regularities of age and constitutional morphological changes under the conditions of exposure to endo- and exogenous factors and ways of their correction» (No. 0113U001347).

Institution, which financed the research: Ministry of Health of Ukraine.

The authors assume responsibility for the published work.

The authors guarantee absence of competing interests and their own financial interest when carrying out the research and writing the article.

The manuscript was received by the editorial staff 8.08.2020. 
the pineal gland prevents irrationally rapid changes in biorhythms in response to random fluctuations in the light regime [3].

To date, the influence of various external and internal environmental factors has been widely studied, both on the pineal gland (of antipsychotic therapy and neuroleptics [4], electromagnetic radiation [5, 6], light and radiation in the experiment [7, 8], etc.), and parathyroid glands. In particular, the effect of cadmium [9], BIA $10-2474$ - a new inhibitor of fatty acid amidhydrolase (FAAH) [10], infrared radiation [11], immunostimulation [12], autoimmune diseases, metastazing, iron or copper overload, radiation therapy or treatment with radioactive iodine, rare genetic disorders on the parathyroid glands has been studied [13]. In addition, the effect of heavy metal salts on the thyroid gland [14], the pituitary gland and adrenal glands [15], the islet apparatus of the pancreas [16], and others were directly studied.

However, only single studies have been devoted to the study of the epiphyseal-parathyroid axis of the endocrine system: changes of calcemia into melatonin secretion in hemodialysis patients have been studied. In hemodialysis patients with hyperparathyroidism, parathyroidectomy significantly increases nocturnal melatonin secretion [17]. Participation of the pineal gland in the modulation of the parathyroid hormone (PTH) and calcitonin release in rats after changes in the activity of the cervical sympathetic nerves is studied [18]. In scientific publications there are no works on a comprehensive study of the of the epiphyseal - parathyroid axis structural components in sexually mature male rats under the conditions of readaptation after long-term exposure to the complex of heavy metal salts.

The purpose of the work was to perform a comprehensive study of morphological, biochemical and immunohistochemical parameters of the epiphyseal - parathyroid axis structural components in sexually mature male rats under the conditions of readaptation after longterm exposure to a complex of heavy metal salts.

\section{MATERIALS AND METHODS}

The experiment was performed on 24 white sexually mature male rats weighing $250-300 \mathrm{~g}$, aged 7-8 months, which were divided into 2 groups (the control and the experimental ones). Animals of the both groups were kept in the normal vivarium conditions, where the equal keeping conditions, nutrition, proper care and natural light (day/night) were maintained. The animals had free access to drinking water. The study was carried out in the autumnwinter period. The experimental group included rats in the readaptation period, which were kept on a regular drinking and food diet for 30 days after 90 days of drinking water mixture with heavy metal salts: zinc $\left(\mathrm{ZnSO}_{4} \cdot 7 \mathrm{H}_{2} \mathrm{O}\right)-$ $5 \mathrm{mg} / \mathrm{l}$, copper $\left(\mathrm{CuSO}_{4} \cdot 5 \mathrm{H}_{2} \mathrm{O}\right)-1 \mathrm{mg} / \mathrm{l}$, iron $\left(\mathrm{FeSO}_{4}\right)-10 \mathrm{mg} / \mathrm{l}$, manganese $\left(\mathrm{MnSO}_{4} \cdot 5 \mathrm{H}_{2} \mathrm{O}\right)-$ $0.1 \mathrm{mg} / \mathrm{l}$, lead $\left(\mathrm{Pb}\left(\mathrm{NO}_{3}\right)_{2}\right)-0.1 \mathrm{mg} / \mathrm{l}$ and chromium $\mathrm{K}_{2} \mathrm{Cr}_{2} \mathrm{O}_{7}$ ) $-0.1 \mathrm{mg} / \mathrm{l}$. The selected concentration of salts in the mixture was due to the presence of such concentrations of these salts in the soil and drinking water of Ukraine some regions according to literature sources $[1,2]$.

Groups of experimental animals were removed from the experiment after previous thiopental anesthesia (at the rate of 30-40 mg / $10 \mathrm{~g}$ body weight) on the $120^{\text {th }}$ day of the experiment, in compliance with national standards on bioethics. The subjects of the study were the pineal gland and the parathyroid glands of experimental and control animals. Histological features of the organs were studied using serial-step sections stained with hematoxylin-eosin. Determination of Ki-67 proliferation marker's expression was performed by immunohistochemical method on deparaffinized sections of organs according to standard methods. Rabbit monoclonal antibodies (clone SP6 for determining Ki-67, USA) with a titer of 1:100 according to the manufacturer's recommendations were used for the reaction. Assessment of Ki-67 proliferation marker's expression was performed according to [19]. The parathyroid glands' functional status was assessed by determining PTH $(\mathrm{pg} / \mathrm{ml})$ in the peripheral blood serum of experimental animals (using enzyme immunoassay (EIA) method). The hormone level was determined using reagents produced by Siemens series 0342 (valid until 11.2015) with Immulite 1000 Siemens Healtheare Global (USA) automatic immunochemiluminescent analyzer-photometer. The level of calcium 
$\mathrm{Ca}^{2+}(\mathrm{mmol} / \mathrm{l})$ in the blood serum was determined using OLYMPUS AU 400 biochemical analyzer (Japan). Blood sampling in rats was performed by puncture of the caudal vein immediately before decapitation, in the morning, from 6 to 8 a.m.

Blood was collected into tubes, centrifuged for $20 \mathrm{~min}$ at $+4{ }^{\circ} \mathrm{C}(1000 \mathrm{~g})$, followed by the serum sampling. All samples were analyzed in two steps. Reliability of the difference between experimental and control data of biochemical parameters was calculated in the software package «Statistica 8.0», using the Student's t test. The error probability of less than $5 \%$ $(\mathrm{p} \leq 0.05)$ was considered sufficient.

\section{RESULTS AND THEIR DISCUSSION}

Long-term, for 90 days, the effect on the body of experimental animals of a salts of heavy metals mixture adversely affects the various structural components of the thyroid gland and pineal gland. Thus, in the thyroid gland there was swelling, increase in the area of the glands and significant growth of connective tissue in the parenchyma of the organ. Tentorial properties changed in parathyrocytes, their nuclei acquired different sizes and shapes. There is a suppression of parathyroid hormone secretion, and also a decrease in serum calcium [20] (Fig. 1A). In the structure of the pineal gland on the $90^{\text {th }}$ day of the experiment there is a thickening of the capsule and dilation of the intertrabecular spaces, dystonic changes in the vascular bed with signs of impaired rheological properties of blood (blood stasis, erythrocyte aggregation, sludge phenomenon, impaired vascular wall permeability). A fairly pronounced active glial reaction in the form of reactive astrogliosis was formed. Pericellular edema formed around some pinealocytes. Their cyto-

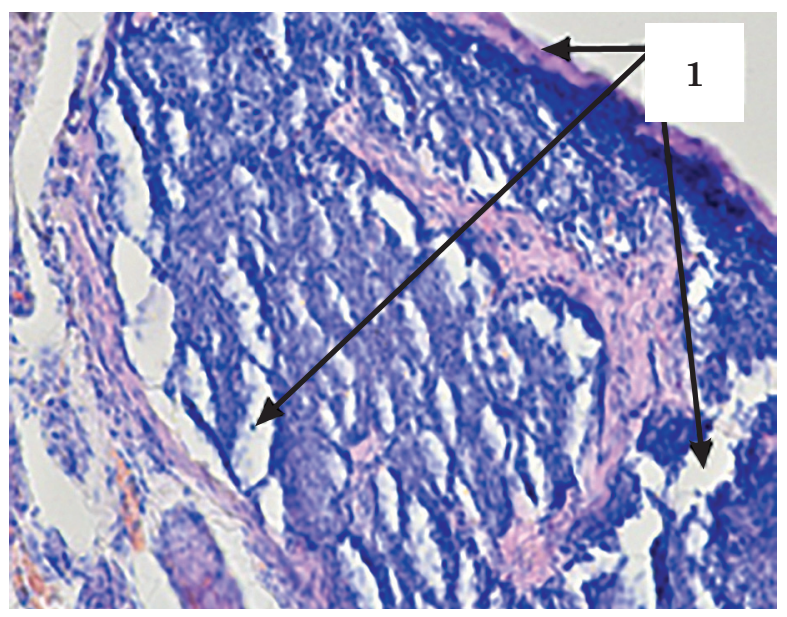

A plasm was enlightened, often vacuolated. The parenchyma of the gland had a moderate number of small, medium, and in some areas single large cysts, stained oxyphilic (Fig. 1B). Thus, under conditions of 90-day intake of a mixture of salts of heavy metals in the body of rats, more pronounced morphofunctional changes are observed in the thyroid gland in comparison with changes in the pineal gland.

After 120 days of the experiment, the pineal gland of the experimental animals was slightly reduced in size. Heavy metal salts caused noticeable negative changes in all structural components of the gland: stromal, vascular and parenchyma. There was a slight thickening and swelling of the pineal gland's interstitium, especially the trabeculae. But the most pronounced morphological changes were determined in the vascular bed: thickening in the vessel wall of medium and large caliber, a pronounced impairment of the blood rheological properties (blood stasis, erythrocyte aggregation, a pronounced sludge phenomenon).

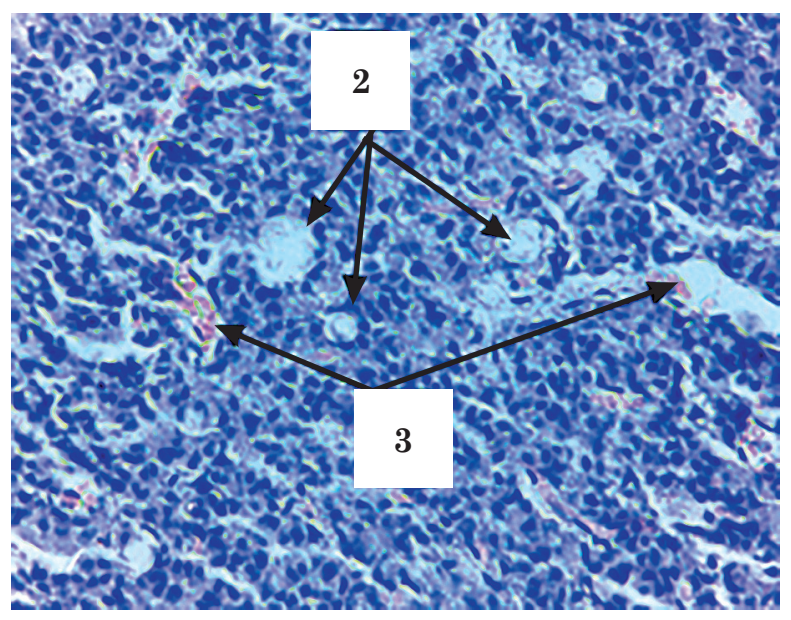

B

Fig. 1. Morphological rearrangements of the structural components of the thyroid gland (A) and pineal gland (B) under the conditions of 90-day exposure to heavy metal salts: 1 - growth of connective tissue; 2 - violation of the rheological properties of blood; 3 - formation of multiple cysts. Hematoxylin-eosin staining. $\times 400 x$. 
Particular attention is drawn to the impairment of the vascular wall's permeability, with the infiltration of plasma and blood cells into the extravascular space. These processes were particularly pronounced in the subcapsular zone, where microhemorrhages of various sizes and diffuse permeation of the pineal gland's peripheral areas with erythrocytes and formation of an active glial reaction were contoured. Perivascular edema was visualized around the vessels. In one of the fields of view near the vascular fascicle, local growth of connective tissue was observed. Pinealocytes have also undergone morphological changes. The specimens were dominated by light pinealocytes with cleared cytoplasm and sharply basophilic, homogeneous nuclei, which shape changed from oval to indeterminate and somewhat elongated, angular. Nucleoli had only single nuclei of pinealocytes. Pericellular edema persisted around the cells. The cytoplasm of most pinealocytes was vacuolated. The pineal gland's parenchyma had a moderate number of small, oval-shaped cysts that were filled with a light clear fluid (Fig. 2).

Morphological rearrangements of the parathyroid gland were similar to disorders of the structural components in the pineal gland. Capsule thickening, thickening and edema of the stromal connective tissue component were observed. Disorders of hemodynamics in the parathyroid gland were also of nonspecific, polymorphic nature. The gland's large inflow vessels of subcapsular location showed signs of plethora, their vascular wall being thickened. Impairments of the blood rheological properties, with the initial stages of sludging similar to the above were also determined. There was an impairment in the structure of the epithelial trabeculae of the gland, their moderate disintegration. (Fig. 3). The hemocapillaries of the microcirculatory bed, located in the connective tissue trabeculae between the strands of parathyrocytes, were full-blooded, with erythrostasis. In some areas, the initial stages of impaired vascular wall permeability with the formation of single small focal diapedetic microhemorrhages in the extravascular space were determined.

Cellular trabeculae consisted of fine, smallsized parathyrocytes of polygonal and oval shape. Cytoplasm of the cells was stained both in hyper- and hypochromic way. $60-70 \%$ of

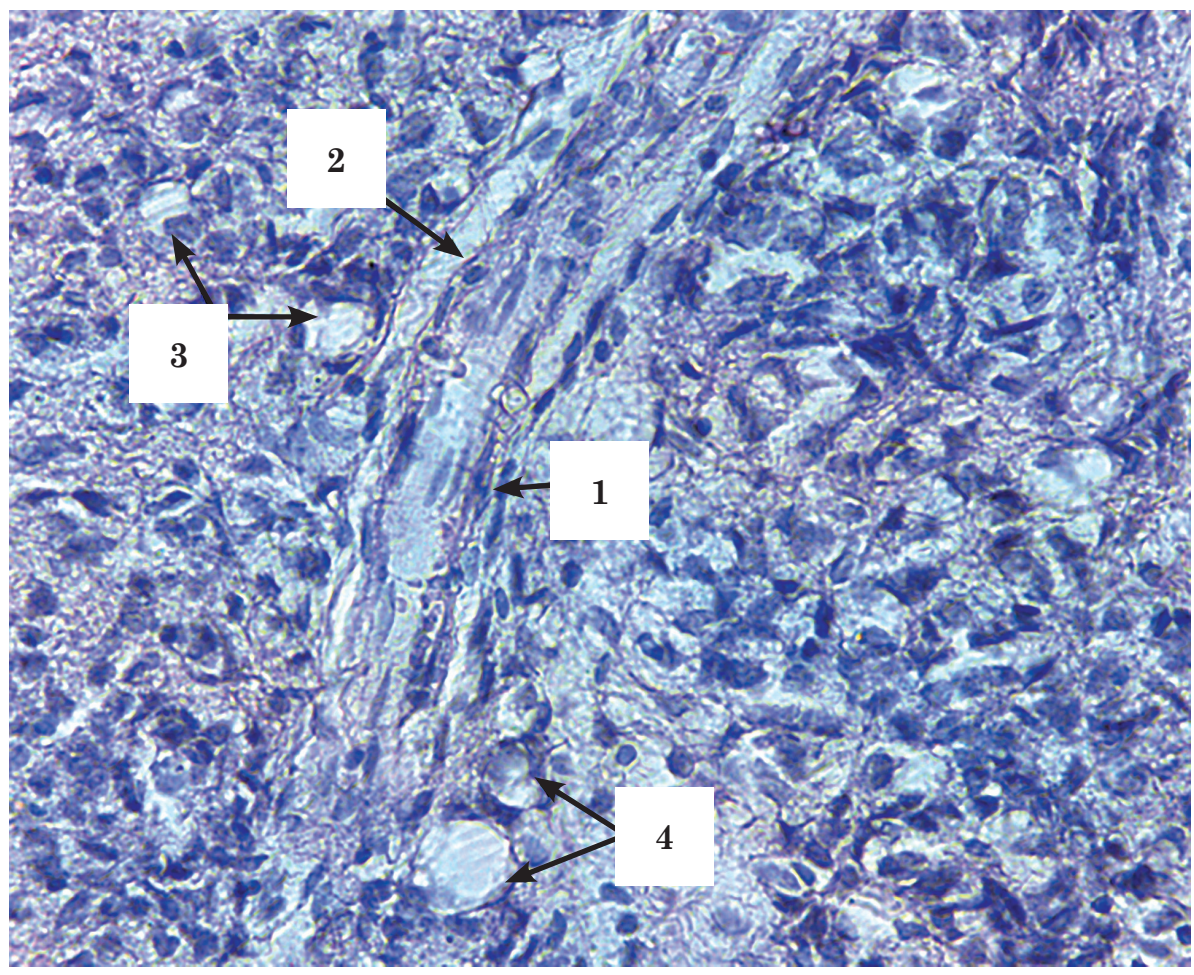

Fig. 2. Morphological rearrangements of the pineal gland's structural components under the conditions of 30 -day readaptation to the 90 -day exposure to heavy metal salts: 1 - thickening of the vessel wall; 2 - perivascular edema; 3 - vacuolated pinealocytes; $4-$ formation of multiple cysts. Hematoxylin-eosin staining. $\times 400 \mathrm{x}$. 


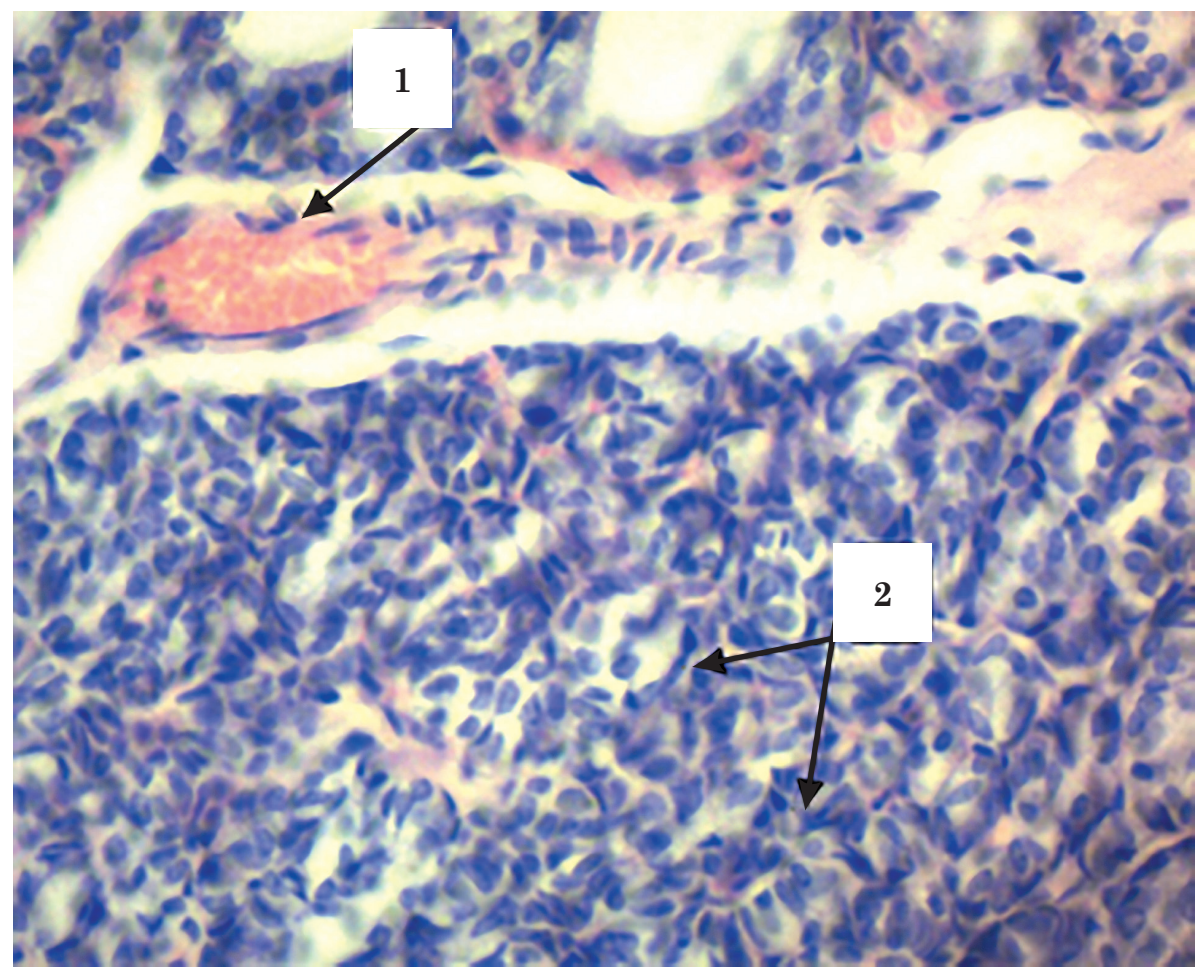

Fig. 3. Morphological changes in the parathyroid gland under the conditions of 30-day readaptation after the 90-day exposure to heavy metal salts: 1 - plethora and thickening of the vessel wall in the subcapsular zone; 2 - disorganization and discomplexation of epithelial trabeculae. Hematoxylin-eosin staining. $\times 400 x$.

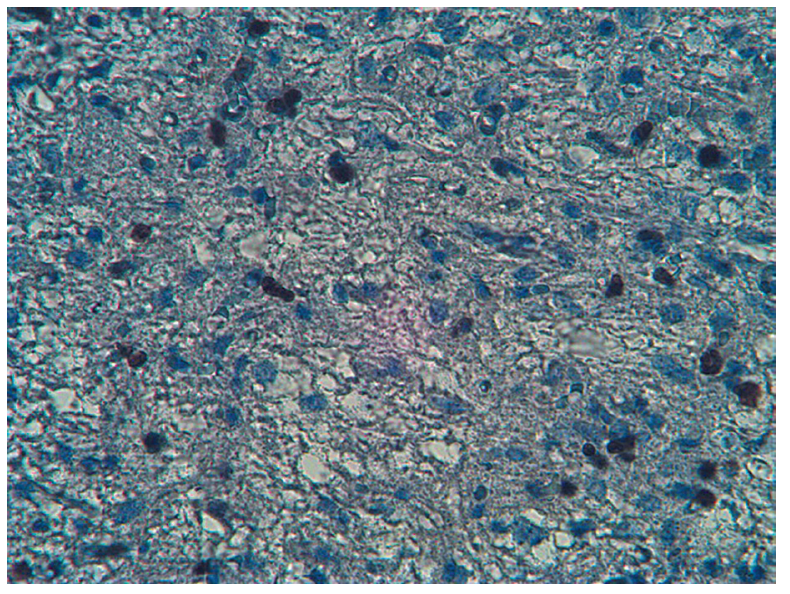

A

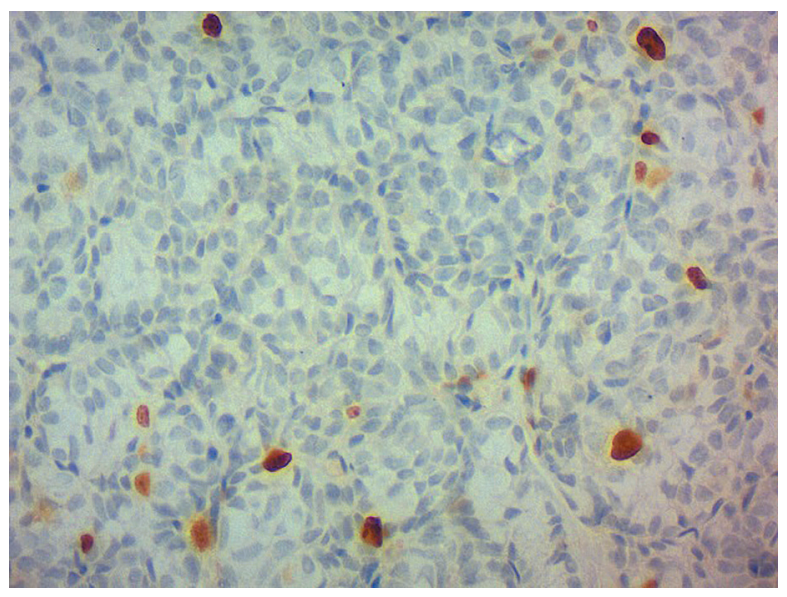

B

Fig. 4. Immunohistochemical study of the pineal gland (A) and parathyroid gland (B)

of experimental rats under the conditions of 30-day readaptation to 90 -day exposure to heavy metal salts. Ki-67 expression in cell nuclei. $\times 400$.

the cells had large oval nuclei, which were located centrally and occupied almost the entire cytoplasm. The nuclear-cytoplasmic ratio was 1: 1-1: 1.2. The chromatin network was cleared, with marginal chromatin aggregation and small, hyperchromic nucleoli located both centrally and in the state of ectopia. There were also nuclei with finely dispersed condensation of chromatin in the form of small pieces, diffusely located in the karyoplasm. 30-40\% of cells had elongated, deformed nuclei. The chromatin network of such nuclei was hyperchromic and homogeneous. According to the results of the experimental animals' blood biochemical examination, it was found that the level of $\mathrm{PT}$ was $<3.0 \mathrm{pg} / \mathrm{ml}$ in the blood serum of both 
Results of parathyroid hormone and calcium determination in the blood serum of experimental and control animals $(M \pm m), n=6$

\begin{tabular}{c|c|c}
\hline \multirow{2}{*}{ Index } & \multicolumn{2}{|c}{ Animal groups under study } \\
\cline { 2 - 3 } & Control animals & Experimental animals \\
\hline PT hormone level $(\mathrm{pg} / \mathrm{ml})$ & $<3.0$ & $<3.0$ \\
\hline PT. optical density $(\mathrm{RU})$ & $67.513 \pm 0.331$ & $58.234 \pm 0.107 * * *$ \\
\hline Calcium $\mathrm{Ca}^{2+}(\mathrm{mmol} / \mathrm{l})$ & $3.030 \pm 0.035$ & $2.883 \pm 0.023^{* *}$ \\
\hline
\end{tabular}

Note: Reliable compared to the control:

* $\quad \mathrm{p} \leq 0.05$;

$* * \quad \mathrm{p} \leq 0.01$

$* * * \mathrm{p} \leq 0.001$.

control and experimental animals. The optical density of PT in the blood serum of rats was studied, taking into account the BoogerLambert-Behr law, which indicates that the optical density of the solution is directly proportional to the concentration of the analyzed speech. The optical density of this hormone was significantly lower than that of the control animals by $13.7 \%(p<0.001, t=26.67415)$. The level of $\mathrm{Ca}^{2+}$ in the blood of experimental animals also changed and was reliably lower than that of the control animals by $4.9 \%(\mathrm{p}<0.01$, $\mathrm{t}=3.478271)$ (Table 1). This indicates a decrease in the concentration of PT and calcium in the blood serum of experimental animals compared to animals in the control group.

According to the results of immunohistochemical study on the expression of Ki-67 proliferative activity marker, it was determined that in the conditions of readaptation, on the 120 th day of the experiment, expression of Ki-67 was observed in about $10 \%$ of parathyroid gland's parenchyma cell nuclei, that practically did not differ from the control and was assessed as weak proliferative activity of the gland. The color intensity of cell nuclei was assessed as moderate (++) and high $(+++)$. Assessment of the $\mathrm{Ki}-67$ protein expression level in the pineal gland neuroglia cells also revealed its weak proliferative activity in the nuclei of peripheral cells $(18 \%)$. The color intensity of the nuclei was assessed as low (+) and moderate $(++)$. We determined the glial reaction in the subcapsular areas of the pineal gland in combination with the practical areactivity of the cell nuclei of the central parts of the gland (Fig. 4).
Analysis of literature data showed that the pineal gland hormones, in particular [3], have a regulatory effect on the secretion of the parathyroid gland hormones and calcium metabolism in the body. Under the conditions of 30-day readaptation to the action of a number of heavy metal salts in the structural components of the central and peripheral links' endocrine glands morphological rearrangements develop having nonspecific polymorphic nature and being similar in most cases. Influenced by a complex of heavy metal salts, in the pineal and the thyroid glands, hemodynamic disorders and the blood rheological properties disorders still persist, with greater severity in the pineal gland, which can be explained by anatomical structure features of the organ, particularly by the lack of blood-brain barrier. The secretory activity of pinealocytes in the experimental animals is slightly increased compared to the control group animals, as evidenced by vacuolation of their cytoplasm and formation of multiple cysts in the parenchyma of the gland. The presence of pinealocytes with angular nuclei and highly vacuolated cytoplasm in the gland parenchyma, according to a number of authors $[6,21]$, indicates the synthesis and accumulation of indolamines in these cells. However, most of the pinealocytes showed signs of activation of polypeptide synthesis.

The neuroglia reaction is also activated in response to the damaging agent, especially in the peripheral subcapsular areas of the gland. Formed perivascular astroglial complexes, according to [22] may indirectly indicate more intense processes of apoptosis of pinealocytes in these animals. According to modern views 
on the functions and morphology of astroglia [23], astrocytes have the ability to synthesize gas transmitters, including carbon monoxide (CO), which is involved in the mechanisms of inflammation and apoptosis. In addition, the increase in the number of glial elements in the pineal gland certainly have a certain compensatory-adaptive value, especially in the transfer of RNA, amino acids, growth factors and controlling water-ion homeostasis in the gland [23]. In addition, according to the authors, such proliferates have a barrier function, preventing the penetration of heavy metals into the parenchyma of the gland. It is impossible to overestimate the contribution of astrocytes in the protection of the parenchyma of the gland from oxidative stress through the synthesis of hydrogen sulfide (H2S). This gas gliotransmitter has the properties of a synaptic modulator and a neuroprotector, protecting against oxidative stress [23]. But the transport of hormones into the vascular bed is significantly complicated as a result of the hormone diffusion processes impairment through the plasmalemma of pinealocytes, impairment of the normal morphological structure of the vascular wall's capillaries and disorders of the blood rheological properties. This fact, of course, adversely affects the secretory activity of the parathyroid gland. Pathogenetically dystrophic changes of the endocrine glands' vascular bed negatively affect the morphofunctional and secretory activity of glandulocytes. Thus, against the background of parathyrocytes' weak proliferative activity a decrease in their secretory activity and as a result, the reduced amount of parathyroid hormone and $\mathrm{Ca}^{2+}$ is observed in the blood of experimental animals compared to the controls. However, a number of morphological features of parathyroid cell nuclei (increase in the number of nuclei with euchromatin and nucleoli, chromatin margination [24] undoubtedly indicate a slight increase in functional activity and strains of adaptive processes in the part of parathyroid glandular cells under the conditions of 30-day readaptation to the action of the damaging agent. Undoubtedly, this fact permits to assume, that further extension of readaptation terms can positively effect the homeostasis in the epiphysal-parathyroide axis in the studied animals and will cause the absolute or partial compensation of the damaging agent's effect on the studied animals' body.

\section{CONCLUSION}

Thus, the 30-day period of readaptation after 90 days of heavy metal salts intake is insufficient for the complete restoration of homeostasis in the epiphyseal-parathyroid system. Analyzing the morphofunctional rearrangements of the studied glands, it is necessary to note the greater vulnerability of the thyroid gland to the action of heavy metal salts and in turn the faster dynamics of the regenerative processes in the thyroid gland compared to the pineal gland. In its turn, development of the parathyroide gland's hypofunction undoubtedly has a negative impact on the overall calcium metabolism in the body, development of compensatory-adaptive processes and the course of the general adaptation syndrome in response to the damaging agent.
Thus, in our opinion, according to the fivephase model of chronic stress [25], the epiphyseal-parathyroid axis of the endocrine system in experimental animals during 30 days of readaptation after 90 days of exposure to heavy metal salts is at the stage of chronic stress «subcompensation».

Prospects for further research are based on further morphological, immunohistochemical and biochemical studies of the pineal gland and the parathyroid gland of rats under the conditions of readaptation to the action of a heavy metal salts complex and the use of a corrective drug.

\section{REFERENCES}

1. Romaniuk A, Lyndin M, Lyndina Y, et al. Turkish $J$ Pathol 2018; 34: 73-81. doi: 10.5146/tjpath.2017.01412.

2. Romanyuk AM, Hryntsova NB, Karpenko LI, et al. Probl Endocrin Pathology 2019; 2: 98-103.
3. Stepovaya EA. The effect of epiphysectomy on the circadian rhythm of total calcium concentration in blood plasma and rhythmostasis in rats, Stavropol, 2001: $27 \mathrm{p}$. 
4. Volkov VP. Universum: Medicine and Pharmacology Electron Sci Zhurn 2014; 9(10), available at : http:// 7universum.com/en/med/archive/item/1590.

5. Bondarenko LO. Ukr Radiol J 2001; 9: 298-302.

6. Denisenko SA, Gubina-Vakulik GI. Probl Endocrin Pathology 2009; 4: 112-117.

7. Logvinov SV, Gerasimov AV, Kostyuchenko VP. Bull Siberian Med 2003;3: 36-43.

8. Pshichenko VV. Kuban Sci Med Bull 2014; 1(143): 150154.

9. Srivastav AK. Srivastava SK. Iran J Toxicol 2019; 13(3): 39-44

10. Hayes AW, Hardisty JF, Harris SB. Regul Toxicol Pharmacol 2020; 111: 104540. doi: 10.1016/j.yrtph.2019. 104540.

11. Serra C, Silveira L. Lasers Med Sci 2020; 35(1): 107-114. doi: 10.1007/s10103-019-02800-w.

12. Avilova O, Erokhina V. Balkan Med Union 2019; 54(2): 227-234. doi: 10.31688/ABMU.2019.54.2.02.

13. Hemida AH, Aljaberi KK, Alsammahi AA, Althagafi HM. Indo Am J Pharm Sci 2019; 6(1): 1526-1530.

14. Moskalenko RA, Romanyuk AM, Budko GYu, et al. Ukr Morph Almanach 2010; 8(1): 60-65.

15. Kashirina NK, Andybura NYu, Rogozin OV. Taurichesky Med-Biol Bull 2005; 8(3): 48-51.
16. Kravets OV. Ukr Morph Almanach 2009; 7(1): 36-37.

17. Kancheva R, Sulkova S, Svara F. Physiol Res 2008; 57(1): 181-185.

18. Stern JE, Esquifino AI, Bonacho MG. J Pineal Res 1997; 22(1): 9-15.

19. Lutsik SO, Yashchenko AM. World Med Biol 2018; 4(66): $175-180$.

20. Romanyuk AM, Timakova OO, Lindina YuM, et al. Bull Vinnytskia Nat Med Un-ty 2019; 23(1): 80-83.

21. Bondarenko LA, Gubina-Vakulik GI, Gevorgyan AR. Pineal gland and hypothalamic-pituitary-thyroid system: age and chronobiological aspects, Kharkiv, 2013: $262 \mathrm{p}$.

22. Gubina-Vakulik GI. Bukovina Med Bull 2006; 10(4): 34-36.

23. Goryainov SA, Protsky SV, Okhotin VE et al. Anal Clin Experim Neurol 2013; 7(1): 45-51.

24. Shkorbatov YuG. Structural and electrochemical power of the nuclei of the civil society of people with the sound of physical and chemical factors and the great functionality of the body, Kiev, 2005: $27 \mathrm{p}$.

25. Kirillov OI, Khasina YeI. Visn Khark Natsional Un-tu im. VN. Karazina. Medytsyna 2003; 581(5): 57-58.

\section{МОРФОФУНКЦІОНАЛЬНІ ПЕРЕБУДОВИ СТРУКТУРНИХ КОМПОНЕНТІВ ЕПІФІЗАРНО-ПАРАТИРЕОЇДНОЇ ВІСІ ЩУРІВ В ПЕРІОД РЕАДАПТАЦІІ ПІСЛЯ ДОВГОТРИВАЛОГО ВПЛИВУ СОЛЕЙ ВАЖКИХ МЕТАЛІВ}

Гринцова Н. Б., Тимакова О. О., Романюк А. М.

Сумський державний університет, медичний інститут, кафедра морфологї, каферра патологічної анатолії, м. Суми, Україна natalia.gryntsova@gmail.com

Важливою екологічною проблемою е забруднення навколишнього середовища солями важких металів, які знаходяться у різноманітних комбінаціях в залежності від регіону та зумовлюють несприятливий вплив на здоров'я населення. Ендокринна система разом з імунною та нервовою підтримуе гомеостаз у організмі. 3 метою вивчення морфофрунціональних перебудов структурних компонентів епіфрізарно-паратиреоїдної вісі щурів в період 30-ти денної реадаптації після 90-то денного впливу солей важких металів $\left(\mathrm{ZnSO}_{4} \cdot 7 \mathrm{H}_{2} \mathrm{O}\right)-5$ мг/л, $\left(\mathrm{CuSO}_{4} \cdot 5 \mathrm{H}_{2} \mathrm{O}\right)-1$ мг/л, $\left(\mathrm{FeSO}_{4}\right)-10$ мг/л, $\left(\mathrm{MnSO}_{4} \cdot 5 \mathrm{H}_{2} \mathrm{O}\right)-$ 0,1 мг/л, $\left(\mathrm{Pb}\left(\mathrm{NO}_{3}\right)_{2}\right)-0,1 \mathrm{мг/л} \mathrm{та}\left(\mathrm{K}_{2} \mathrm{Cr}_{2} \mathrm{O}_{7}\right)-0,1 \mathrm{мг/л)} \mathrm{був} \mathrm{проведений} \mathrm{експеримент} \mathrm{на} 24$ білих статевозрілих щурах-самцях масою 250-300 г, віком 7-8 місяців. Тварини експериментальної групи протягом 30 -ти діб вживали звичайну питну воду. Було застосовано морфологічні, статистичні, імуногістохімічні та біохімічні методи дослідження. 30-ти денний термін реадаптації після 90-то денного надходження в організм солей важких металів є недостатнім для повного відновлення гомеостазу в епіфізарнопаратиреоїдній системі, яка перебувае в стадії «субкомпенсації» хронічного стресу. Було визначено виразні морфологічні перебудови зі сторони судинного русла епіфрізу та прищитоподібної залози (стаз крові, агрегація еритроцитів, сладж-френомен), у епіфізі формувалася активна гліальна реакція, порушувалася будова епітеліальних трабекул залоз. Рівні паратгормону та кальцію в крові експериментальних тварин були достовірно нижчими за показники експериментальних тварин. Відмічена більша уразливість та більш швидка динаміка відновних процесів у прищитоподібній залозі до дії солей важких металів у порівнянні з епіфізом. Розвиток гіпофункції прищитоподібної залози безперечно негативно впливає на загальний кальцієвий метаболізм в організмі, розвиток компенсаторно-пристосувальних процесів та перебіг загального адаптаційного синдрому у відповідь на дію пошкоджуючого агента.

К л юч ов і с лов а : епіфріз, прищитоподібні залози, важкі метали. 


\title{
МОРФОФУНКЦИОНАЛЬНЫЕ ПЕРЕСТРОЙКИ СТРУКТУРНЫХ КОМПОНЕНТОВ ЭПИФИЗАРНО-ПАРАТИРЕОИДНОЙ ОСИ КРЫС В ПЕРИОД РЕАДАПТАЦИИ ПОСЛЕ ДЛИТЕЛЬНОГО ВОЗДЕЙСТВИЯ СОЛЕЙ ТЯЖЕЛЫХ МЕТАЛЛОВ
}

\author{
Гринцова Н. Б., Тимакова А. А., Романюк А.М. \\ Сулский государственный университет, медииинский институт, \\ кафбедра морфбологии, кафбедра патологической анатолии, г. Суль, Украина \\ natalia.gryntsova@gmail.com
}

Важной экологической проблемой является загрязнение окружающей среды солями тяжелых металлов, которые находятся в различных комбинациях в зависимости от региона и обусловливают неблагоприятное воздействие на здоровье населения. Эндокринная система вместе с иммунной и нервной поддерживает гомеостаз в организме. С целью изучения морфофункциональных перестроек структурных компонентов эпифизарно-паратиреоидной оси крыс в период 30 -ти дневной реадаптации после 90-то дневного воздействия солей тяжелых металлов $\left(\mathrm{ZnSO}_{4} \cdot 7 \mathrm{H}_{2} \mathrm{O}\right)-5$ мг/л, $\left(\mathrm{CuSO}_{4} \cdot 5 \mathrm{H}_{2} \mathrm{O}\right)-$ 1 мг/л, $\left(\mathrm{FeSO}_{4}\right)-10 \mathrm{мг/л,}\left(\mathrm{MnSO}_{4} \cdot 5 \mathrm{H}_{2} \mathrm{O}\right)-0,1 \mathrm{мг/л,}\left(\mathrm{Pb}\left(\mathrm{NO}_{3}\right)_{2}\right)-0,1$ мг/л и $\left(\mathrm{K}_{2} \mathrm{Cr}_{2} \mathrm{O}_{7}\right)-0,1$ мг/л) был проведен эксперимент на 24 белых половозрелых крысах-самцах массой 250-300г в возрасте 7-8 месяцев. Животные экспериментальной группы в течение 30-ти суток употребляли обычную питьевую воду. Применялись морфологические, статистические, иммуногистохимические и биохимические методы исследований. 30-ти дневный срок реадаптации после 90-то дневного поступления в организм солей тяжелых металлов является недостаточным для полного восстановления гомеостаза в эпифизарно-паратиреоидной системе, которая находится в стадии "субкомпенсации» хронического стресса. Были определены (выявлены) выразительные морфологические перестройки со стороны сосудистого русла эпифиза и паращитовидных желез (стаз крови, агрегация эритроцитов, сладж-френомен), в эпифизе формировалась активная глиальная реакция, нарушалось строение эпителиальных трабекул желез. Уровень паратгормона и кальция в крови экспериментальных животных были достоверно ниже показателей экспериментальных животных. Отмечена большая уязвимость и более быстрая динамика восстановительных процессов в паращитовидных железах к действию солей тяжелых металлов по сравнению с эпифизом. Развитие гипофункции паращитовидных желез, безусловно негативно влияет на общий кальциевый метаболизм в организме, развитие компенсаторно-приспособительных процессов и ход общего адаптационного синдрома в ответ на действие повреждающего агента.

К л ючев ые с лов а : эпифиз, паращитовидные железы, тяжелые металлы.

\section{MORPHOFUNCTIONAL RECONSTRUCTIONS OF THE EPIPHYSAL-PARATHYROIDE AXIS STRUCTURAL COMPONENTS OF RATS IN THE PERIOD OF READAPTATION AFTER PROLONGED EXPOSURE TO HEAVY METALS}

\author{
Hryntsova N. B., Tymakova O. O., Romaniuk A. M. \\ Sumy State University, Medical Institute, Department of Morphology, \\ Department of Pathological Anatomy, Sumy, Ukraine \\ natalia.gryntsova@gmail.com
}

An important environmental problem is the pollution of the environment with heavy metal salts, which are in various combinations depending on the region and cause adverse effects on public health. The endocrine system together with the immune and nervous system maintains homeostasis in the body. In order to study the morphofunctional rearrangements of the epiphyseal-parathyroid axis structural components in rats during 30 days of readaptation after 90 days of exposure to heavy metal salts (zinc $\left(\mathrm{ZnSO}_{4} \cdot 7 \mathrm{H}_{2} \mathrm{O}\right)-5 \mathrm{mg} / \mathrm{l}$, copper $\left(\mathrm{CuSO}_{4} \cdot 5 \mathrm{H}_{2} \mathrm{O}\right)-1 \mathrm{mg} / \mathrm{l}$, iron $\left(\mathrm{FeSO}_{4}\right)-10 \mathrm{mg} / \mathrm{l}$, manganese $\left(\mathrm{MnSO}_{4} \cdot 5 \mathrm{H}_{2} \mathrm{O}\right)-0.1 \mathrm{mg} / \mathrm{l}$, lead $\left(\mathrm{Pb}\left(\mathrm{NO}_{3}\right)_{2}\right)-$ $0.1 \mathrm{mg} / \mathrm{l}$ and chromium $\left.\mathrm{K}_{2} \mathrm{Cr}_{2} \mathrm{O}_{7}\right)-0.1 \mathrm{mg} / \mathrm{l}$ ) an experiment was performed on 24 white sexually mature male rats weighing 250-300 g, aged 7-8 months. The animals of the experimental group consumed ordinary drinking water for 30 days. Morphological, statistical, immunohistochemical and biochemical research methods were used. The 30-day period of readaptation after 90 days of heavy metal salts intake is insufficient to completely restore homeostasis in the epiphyseal-parathyroid system, which is at the stage of chronic stress "subcompensation». Significant morphological changes on the part of the vascular bed of the pineal gland and parathyroid glands (blood stasis, erythrocyte aggregation, sludge phenomenon) were determined, an active glial reaction was formed in the pineal gland, and the structure of the epithelial trabeculae of the glands was disturbed. The levels of parathyroid hormone and calcium in the blood of experimental animals were significantly lower than those of experimental animals. There is a greater vulnerability and faster dynamics of the regenerative processes in the parathyroid glands to the action of salts of heavy metals in comparison with the pineal gland. The development of hypofunction of the parathyroid glands, of course, has a negative effect on the overall calcium metabolism in the body, the development of compensatory and adaptive processes and the course of the general adaptation syndrome in response to the damaging agent.

Key words: pineal gland, parathyroid glands, heavy metals. 